\title{
Cardio-Oncology: mechanisms of cardiovascular toxicity
}

\section{[version 1; peer review: 2 approved]}

\author{
Timothy M. Markman1, Maurie Markman (iD2 \\ ${ }^{1}$ Department of Medicine, Cardiovascular Division, Hospital of the University of Pennsylvania, University of Pennsylvania, \\ Philadelphia, Pennsylvania, USA \\ ${ }^{2}$ Cancer Treatment Centers of America at Eastern Regional Medical Center, Philadelphia, Pennsylvania, USA
}

V1 First published: 25 Jan 2018, 7(F1000 Faculty Rev):113

https://doi.org/10.12688/f1000research.12598.1

Latest published: 25 Jan 2018, 7(F1000 Faculty Rev):113

https://doi.org/10.12688/f1000research.12598.1

\section{Abstract}

The therapeutic options available to treat a wide range of malignancies are rapidly increasing. At the same time, the population being treated is aging with more cardiovascular risk factors, comorbid conditions, and associated poor cardiac reserve. Both traditional chemotherapeutic agents (for example, anthracyclines) and newer therapies (for example, targeted tyrosine kinase inhibitors and immune checkpoint inhibitors) have demonstrated profound cardiovascular toxicities. It is important to understand the mechanisms of these toxicities to establish strategies for the prevention and management of complications-arrhythmias, heart failure, and even death. In the first of this two-part review series, we focus on what is known and hypothesized about the mechanisms of cardiovascular toxicity from anthracyclines, HER2/ErbB2 inhibitors, immune checkpoint inhibitors, and vascular endothelial growth factor inhibitors.

\section{Keywords}

cardiovascular toxicity, cardio-oncology, anthracyclines, HER2/ErbB2 inhibitors, immune checkpoint inhibitors

\section{Open Peer Review}

Approval Status

1

2

version 1

$25 \operatorname{Jan} 2018$

Faculty Reviews are review articles written by the prestigious Members of Faculty Opinions. The articles are commissioned and peer reviewed before publication to ensure that the final, published version is comprehensive and accessible. The reviewers who approved the final version are listed with their names and affiliations.

1. Joerg Herrmann, Mayo Clinic, Rochester, USA

2. Lee Jones, Memorial Sloan Kettering Cancer Center, New York City, USA

Any comments on the article can be found at the end of the article. 
Corresponding author: Maurie Markman (maurie.markman@ctca-hope.com)

Author roles: Markman TM: Conceptualization, Writing - Original Draft Preparation, Writing - Review \& Editing; Markman M: Conceptualization, Supervision, Writing - Review \& Editing

Competing interests: No competing interests were disclosed.

Grant information: The author(s) declared that no grants were involved in supporting this work.

Copyright: ( $) 2018$ Markman TM and Markman M. This is an open access article distributed under the terms of the Creative Commons Attribution License, which permits unrestricted use, distribution, and reproduction in any medium, provided the original work is properly cited.

How to cite this article: Markman TM and Markman M. Cardio-Oncology: mechanisms of cardiovascular toxicity [version 1; peer review: 2 approved] F1000Research 2018, 7(F1000 Faculty Rev):113 https://doi.org/10.12688/f1000research.12598.1

First published: 25 Jan 2018, 7(F1000 Faculty Rev):113 https://doi.org/10.12688/f1000research.12598.1 


\section{Introduction}

Cardiovascular disease and cancer remain leading causes of mortality in the United States. Given the rapid expansion in the number of therapeutic options for cancer, the development of cardiovascular disease in these patients presents a growing challenge for both oncologists and cardiologists. Overlapping risk factors for cancer and cardiovascular disease, especially tobacco use and advanced age, play a significant role in this association ${ }^{1}$. Additionally, improved survival has helped to highlight the cardiac toxicity that results from antineoplastic therapy as patients are living long enough to experience adverse effects from these complications. This has been especially true in pediatric cancer survivors who have demonstrated increased rates of cardiovascular disease several decades after therapy ${ }^{2-4}$.

Antineoplastic agents from multiple classes affect cardiac tissue and result in myocardial cellular damage, ultimately leading to a range of clinically important effects, including electrophysiological abnormalities, symptomatic heart failure (HF), and even death. The rate of dangerous ventricular arrhythmias may increase by 10 -fold in patients with cancer, and chemotherapyinduced cardiomyopathy has been reported in $1-5 \%$ of cancer survivors and is substantially higher in certain populations ${ }^{5-7}$. These toxicities represent a limiting factor in the therapy of several otherwise-treatable neoplasms, and an aging population with impaired cardiac reserve may be even more susceptible to these effects ${ }^{8,9}$. In this review, we explore both established and theoretical mechanisms of cardiac toxicity contributing to cardiovascular disease from several important classes of antineoplastic therapy.

\section{Anthracyclines}

Anthracycline-induced cardiomyopathy was the earliest-described form of cardiotoxicity from chemotherapy. Accordingly, the mechanism has been the most thoroughly investigated and represents the broad effects and toxicities of traditional chemotherapeutic agents. This type of cardiotoxicity causes cardiomyocyte death and traditionally has been referred to as type $\mathrm{I}^{10,11}$. Anthracyclines are highly effective agents, but this toxicity, which is dose-dependent, limits their use. Cumulative anthracycline dose is capped at less than $500 \mathrm{mg} / \mathrm{m}^{2}$ on the basis of evidence that is largely from retrospective analyses from clinical trials in adults and that suggests the rates of incidence of $\mathrm{HF}$ due to doxorubicin are $1.7 \%$ with a cumulative dose of $300 \mathrm{mg} / \mathrm{m}^{2}$ and $4.7 \%$ with a cumulative dose of $400 \mathrm{mg} / \mathrm{m}^{2}$ and increase rapidly to $15.7 \%$ at $500 \mathrm{mg} / \mathrm{m}^{2}$ and $48 \%$ at $650 \mathrm{mg} / \mathrm{m}^{212}$. Cumulative doses in patients with pre-existing cardiac dysfunction can be more challenging to determine.

Anthracycline toxicity can be categorized as acute, earlyonset chronic progressive, or late-onset chronic progressive ${ }^{13}$. Acute toxicity is rare and occurs within hours or days of infusion and is generally reversible. This type of cardiotoxicity is not predictive of future HF and represents a small minority $(1 \%)$ of cases. Early-onset chronic progressive toxicity represents the majority of cases of anthracycline cardiotoxicity and occurs within one year of therapy, whereas late onset is uncommon and occurs after one year of therapy ${ }^{14}$. Although these manifestations may not occur for several years after completion of therapy, evidence from biopsy studies suggests that the initial insult occurs from the onset of therapy ${ }^{15}$. Accordingly, several techniques in imaging and electrocardiographic monitoring are under investigation in order to make an early determination of which patients are experiencing cardiac toxicity ${ }^{16,17}$.

The therapeutic mechanism of action of anthracyclines involves the interruption of replicating cells through intercalation with DNA as well as the inhibition of topoisomerase II. The mechanisms of cardiac toxicity have not been conclusively established but are widely accepted to relate to multiple pathways of oxidative stress through the formation of reactive oxygen species. Interaction occurs both with topoisomerase II $\alpha$, which is overexpressed in malignant cells and is one of the therapeutic targets, and with topoisomerase II $\beta$, which is expressed in cardiomyocytes. Several mechanisms of the effect on topoisomerase II have been proposed, including interactions with the GTPase Rac1 and peroxisome proliferator-activated receptor $\gamma$ coactivator- $1 \alpha^{18-20}$. Furthermore, it seems that anthracyclines may directly impair the proliferation of cardiac progenitor cells, which impair recovery from physiologic and pathologic stressors and inhibit pro-survival signaling pathways of ErbB and NRG-1 ${ }^{21-24}$. Based on these proposed mechanisms of toxicity, many therapies-both novel and those with existing use in the treatment of cardiovascular conditions-have been considered to prevent or reverse anthracycline-induced cardiotoxicity. These agents include common cardiac medications such as 3-hydroxy3-methylglutaryl-coenzyme A (HMG-CoA) reductase inhibitors (or statins), $\beta$-blockers, or angiotensin-converting enzyme (ACE) inhibitors and novel agents such as dexrazoxane. Their use and the evidence behind them will be discussed in the second part of this review series.

\section{HER2/ErbB2 inhibitors}

Although anthracyclines dominated the literature and clinical concern for cardiac toxicity of antineoplastic therapy for many years, the now-widespread use of trastuzumab-a monoclonal antibody directed against HER2/ErbB2 receptors-for the treatment of breast cancers that overexpressed HER2/ErbB2 revealed an overlapping but distinct phenotype of cardiac toxicity ${ }^{25}$. Trastuzumab fits into a category of targeted antineoplastic therapy that, as opposed to traditional chemotherapeutic agents (including anthracyclines), has a generally more favorable safety profile. Nevertheless, trastuzumab causes reduced cardiac function (specifically reduction in left ventricular systolic function) that is clinically similar to that caused by anthracyclines. The mechanism, however, is unique and appears to result in non-dose-dependent cardiomyocyte dysfunction rather than the cell death caused by anthracyclines ${ }^{26}$. Supporting this distinction, endomyocardial biopsies from patients with trastuzumab cardiac toxicity do not demonstrate the anthracyclinerelated structural changes that have been well established ${ }^{27,28}$. When trastuzumab is combined with anthracycline therapy, the cardiotoxicity has been shown to be profound and noted in over $25 \%$ of the patients treated with both agents ${ }^{29,30}$. When used without anthracyclines, trastuzumab is associated with $\mathrm{HF}$ in about $2-4 \%$ of patients ${ }^{26,31}$. 
The mechanism of cardiac toxicity from trastuzumab is related to selective targeting of tyrosine kinases that have both "on-target" and "off target" effects on the heart. Inhibition of ErbB2/HER2 and subsequently reduced ErbB signaling in cancer cells results in cell-mediated cytotoxicity, the major proposed mechanism of trastuzumab's therapeutic effect for breast cancers with overexpression of this pro-survival pathway. However, ErbB is one of the aforementioned pro-survival signaling pathways in cardiomyocytes that are possibly affected by anthracyclines and this "on-target" inhibition is speculated to be the major mechanism of cardiac toxicity. Supporting this theory, mutation or deletion of HER2 is known to be associated with dilated cardiomyopathy in mice with exaggerated sensitivity to pressure overload ${ }^{32,33}$. The more favorable cardiac safety profiles of two other HER2 inhibitors - lapatinib and pertuzumab-have raised questions of additional "off-target" effects of trastuzumab-mediated toxicity, although the mechanisms are less well characterized ${ }^{34-38}$.

Although the cardiac toxicity of trastuzumab is generally considered to be reversible with discontinuation of therapy, the role for guideline-directed medical therapy for left ventricular dysfunction such as $\beta$-blockers or ACE inhibitors is less well established. The use of these agents and other preventative strategies, such as exercise, will be discussed in the second part of this review series.

\section{Immune checkpoint inhibitors}

Remarkable progress has been made in the management of several malignancies, including advanced melanoma, with the use of agents that inhibit immune checkpoint mediators. The first two agents in this class-ipilimumab and nivolumab-have dramatically altered the landscape of antineoplastic therapy but have also been associated with autoimmune adverse reactions ${ }^{39,40}$. By allowing the immune system to increase its activity against malignant cells, checkpoint inhibitors cause patients to become more vulnerable to attacks on healthy tissue, causing autoimmune complications such as hepatitis, pneumonitis, and adrenal insufficiency ${ }^{41,42}$. Recently, cardiotoxicity in the form of potentially fatal myocarditis has been reported, especially with ipilimumab and nivolumab combination therapy ${ }^{43}$. At least 15 cases of cardiotoxicity related to immune checkpoint inhibitors have been reported with manifestations including myocarditis and complete heart block, although these numbers likely underestimate the true incidence ${ }^{44,45}$.

Based on biopsies from tumor as well as heart and skeletal muscle in two patients who experienced fulminant myocarditis, Johnson et al. suggested that activated $\mathrm{T}$ cells may be targeting an antigen shared by the tumor and myocytes in skeletal and cardiac muscle. This "on-target" effect ultimately results in autoimmune myocarditis and myositis ${ }^{43}$. In the inflammatory state, it also appears that PD-L1, which was expressed on the injured myocytes, is protective and its inhibition by these agents contributes to cardiomyocyte vulnerability to injury ${ }^{46}$. Although few guidelines exist on the management of these complications, the second part of this review series will discuss considerations for prevention, monitoring, and treatment of immunotherapyrelated cardiotoxicity.

\section{Vascular endothelial growth factor inhibitors}

Inhibitors of the vascular endothelial growth factor (VEGF) pathway such as sunitinib and sorafenib are used to treat a variety of malignancies, including renal cell carcinoma and hepatocellular carcinoma. Similar to the other agents discussed above, they are highly effective but often limited by their cardiovascular toxicity, especially hypertension and left ventricular dysfunction. Hypertension has been reported in nearly half of the patients receiving VEGF inhibitors, which can be of varying clinical significance depending on the baseline blood pressure and comorbid conditions ${ }^{47-49}$. Asymptomatic decline in left ventricular function is noted in approximately a quarter of patients, whereas symptomatic HF is seen in $4-8 \%{ }^{47,50}$.

VEGF promotes the growth and development of blood vessels by stimulating tyrosine kinase receptors on the cell surface, a process essential to the growth of various malignancies. The therapeutic mechanism of action of VEGF inhibitors is to bind and inhibit the ATP binding site of these specific kinases, thereby inhibiting the angiogenesis. These agents have been shown in vitro to inhibit doses of kinases, and cardiovascular toxicities from these agents occur through inhibition of both "on-target" and "off-target" kinases ${ }^{51}$.

A variety of mechanisms have been proposed for the hypertension seen with VEGF inhibitors. Endothelin-1, which is a potent vasoconstrictor, is increased with VEGF inhibition, and endothelin antagonism appears to limit the development of hypertension, although the mechanism by which VEGF inhibitors activate endothelin-1 has not been clearly established ${ }^{52,53}$. Increasing evidence suggests that VEGF activates the production and release of nitric oxide, a potent vasodilator, although experimental evidence has not conclusively shown decreased nitric oxide bioavailability with VEGF inhibition ${ }^{54-56}$. The inhibition of angiogenesis in the target malignancy causes some degree of microcapillary rarefaction to occur and with this the peripheral vascular resistance and subsequently the blood pressure would be expected to rise. The clinical significance of this mechanism is very unclear both because of the degree of reduction in capillary density that would be necessary to achieve a significant increase in blood pressure and because the hypertension from VEGF inhibitors has been shown to occur rapidly, usually within hours, whereas microcapillary rarefaction appears to take days to weeks to occur ${ }^{52,57-59}$.

It is likely that the consistent and often marked hypertension that occurs contributes to cardiac dysfunction through increased afterload on the left ventricle ${ }^{18}$. Additionally, inhibition of several kinases has been proposed to contribute to left ventricular dysfunction, although the evidence relies largely on non-human models of unclear clinical significance. Alterations in the activity of AMPK, a kinase which is critical in regulating myocardial energetics and mitochondrial function, are inhibited especially by sunitinib, although the significance of this in humans has not been established ${ }^{60,61}$. ERK, another kinase that is inhibited by sorafenib, is important for cardioprotection with increased stress, which may be especially important in the setting of increased afterload from drug-related systemic hypertension ${ }^{62,63}$. 
Pressure overload in the setting of ERK inhibition may promote apoptosis of cardiomyocytes ${ }^{64,65}$. Some degree of inhibition of many other kinases has been hypothesized to play a role in the development of cardiotoxicity, although the clinical significance of these has not been established. Management of the hypertension and left ventricular dysfunction will be discussed in the second part of this review series.

\section{Conclusions}

Both traditional chemotherapeutic agents and newer therapies have important effects on myocardial tissues resulting in arrhythmias, HF, and death. The mechanism of these toxicities consistently relates to "on-target" therapeutic mechanisms of the antineoplastic agents, suggesting a possibly inescapable link between these life-saving medications and cardiovascular toxicity. As new therapies are developed and especially as they are used in aging populations with diminished cardiac reserve, it is essential that oncologists collaborate closely with cardiologists to monitor for and manage these complications. It is also essential to recognize the multifactorial processes that lead to the development of cardiovascular disease in patients treated for malignancies. In the next installment of this review series, we will discuss the management of cardiac toxicity and how these strategies relate to the proposed mechanisms discussed here.

\section{Competing interests}

The authors declare that they have no competing interests.

\section{Grant information}

The author(s) declared that no grants were involved in supporting this work.
1. Murphy SL, Xu J, Kochanek KD: Deaths: final data for 2010. Natl Vital Stat Rep. 2013; 61(4): 1-117. PubMed Abstract

2. Oeffinger KC, Mertens AC, Sklar CA, et al:: Chronic health conditions in adult survivors of childhood cancer. N Engl J Med. 2006; 355(15): 1572-82. PubMed Abstract | Publisher Full Text

3. F Lipshultz SE, Franco VI, Miller TL, et al:: Cardiovascular disease in adult survivors of childhood cancer. Annu Rev Med. 2015; 66: 161-76. PubMed Abstract | Publisher Full Text | Free Full Text | F1000 Recommendation

4. $\quad$ F Çetin S, Babaoğlu K, Başar EZ, et al:: Subclinical anthracycline-induced cardiotoxicity in long-term follow-up of asymptomatic childhood cancer survivors: Assessment by speckle tracking echocardiography. Echocardiography. 2017. PubMed Abstract | Publisher Full Text | F1000 Recommendation

5. Hequet $\mathrm{O}, \mathrm{Le} \mathrm{QH}$, Moullet I, et al: Subclinical late cardiomyopathy after doxorubicin therapy for lymphoma in adults. J Clin Oncol. 2004; 22(10): 1864-71. PubMed Abstract | Publisher Full Text

6. Chang H, Okwuosa TM, Scarabelli T, et al.: Cardiovascular Complications of Cancer Therapy: Best Practices in Diagnosis, Prevention, and Management: Part 2. J Am Coll Cardiol. 2017; 70(20): 2552-65. PubMed Abstract | Publisher Full Text

7. F Enriquez A, Biagi J, Redfearn D, et al.: Increased Incidence of Ventricular Arrhythmias in Patients With Advanced Cancer and Implantable CardioverterDefibrillators. JACC Clin Electrophysiol. 2017; 3(1): 50-6. Publisher Full Text | F1000 Recommendation

8. Broder H, Gottlieb RA, Lepor NE: Chemotherapy and cardiotoxicity. Rev Cardiovasc Med. 2008; 9(2): 75-83. PubMed Abstract | Free Full Text

9. Markman TM, Nazarian S: Arrhythmia and Electrophysiological Effects of Chemotherapy: A Review. Oncology. 2016; 91(2): 61-8. PubMed Abstract | Publisher Full Text

10. Cardinale D, Colombo A, Lamantia G, et al:: Anthracycline-induced cardiomyopathy: clinical relevance and response to pharmacologic therapy. J Am Coll Cardiol. 2010; 55(3): 213-20. PubMed Abstract | Publisher Full Text

11. Volkova M, Russell R 3rd: Anthracycline cardiotoxicity: prevalence, pathogenesis and treatment. Curr Cardiol Rev. 2011; 7(4): 214-20. PubMed Abstract | Publisher Full Text | Free Full Text

12. Swain SM, Whaley FS, Ewer MS: Congestive heart failure in patients treated with doxorubicin: a retrospective analysis of three trials. Cancer. 2003; 97(11): 2869-79. PubMed Abstract | Publisher Full Text

13. Simůnek $T$, Stérba $M$, Popelová $O$, et al: Anthracycline-induced cardiotoxicity: overview of studies examining the roles of oxidative stress and free cellular iron. Pharmacol Rep. 2009; 61(1): 154-71. PublMed Abstract | Publisher Full Text

14. Jones RL, Swanton C, Ewer MS: Anthracycline cardiotoxicity. Expert Opin Drug Saf. 2006; 5(6): 791-809. PubMed Abstract | Publisher Full Tex

15. Rahman AM, Yusuf SW, Ewer MS: Anthracycline-induced cardiotoxicity and the cardiac-sparing effect of liposomal formulation. Int J Nanomedicine. 2007; 2(4):
567-83.

PubMed Abstract | Free Full Text

16. Markman TM, Markman M: Cardiotoxicity of antineoplastic agents: what is the present and future role for imaging? Curr Oncol Rep. 2014; 16(8): 396. PubMed Abstract | Publisher Full Text

17. Markman TM, Ruble K, Loeb D, et al:: Electrophysiological effects of anthracyclines in adult survivors of pediatric malignancy. Pediatr Blood Cancer. 2017; 64(11): e26556.

PubMed Abstract | Publisher Full Text

18. Hahn VS, Lenihan DJ, Ky B: Cancer therapy-induced cardiotoxicity: basic mechanisms and potential cardioprotective therapies. J Am Heart Assoc. 2014; 3(2): e000665.

PubMed Abstract | Publisher Full Text | Free Full Text

19. Chen Z, Norris JY, Finck BN: Peroxisome proliferator-activated receptor-gamma coactivator-1alpha (PGC-1alpha) stimulates VLDL assembly through activation of cell death-inducing DFFA-like effector B (CideB). J Biol Chem. 2010; 285(34): 25996-6004.

PubMed Abstract | Publisher Full Text | Free Full Text

20. Finck BN, Kelly DP: Peroxisome proliferator-activated receptor gamma coactivator-1 (PGC-1) regulatory cascade in cardiac physiology and disease. Circulation. 2007; 115(19): 2540-8. PubMed Abstract | Publisher Full Text

21. De Angelis A, Piegari E, Cappetta D, et al.: Anthracycline cardiomyopathy is mediated by depletion of the cardiac stem cell pool and is rescued by restoration of progenitor cell function. Circulation. 2010; 121(2): 276-92. PubMed Abstract | Publisher Full Text | Free Full Text

22. Huang C, Zhang X, Ramil JM, et al:: Juvenile exposure to anthracyclines impairs cardiac progenitor cell function and vascularization resulting in greater susceptibility to stress-induced myocardial injury in adult mice. Circulation. 2010; 121(5): 675-83. PubMed Abstract | Publisher Full Text | Free Full Text

23. Horie $\mathrm{T}$, Ono $\mathrm{K}$, Nishi $\mathrm{H}$, et al.: Acute doxorubicin cardiotoxicity is associated with miR-146a-induced inhibition of the neuregulin-ErbB pathway. Cardiovasc Res. 2010; 87(4): 656-64. PubMed Abstract | Publisher Full Text | Free Full Text

24. Liu X, Gu X, Li Z, et al:: Neuregulin-1/erbB-activation improves cardiac function and survival in models of ischemic, dilated, and viral cardiomyopathy. $J A m$ Coll Cardiol. 2006; 48(7): 1438-47.

PubMed Abstract | Publisher Full Text

25. Maurea N, Coppola C, Ragone G, et al:: Women survive breast cancer but fall victim to heart failure: the shadows and lights of targeted therapy. J Cardiovasc Med (Hagerstown). 2010; 11(12): 861-8.

PubMed Abstract | Publisher Full Tex

26. Hudis CA: Trastuzumab--mechanism of action and use in clinical practice. N Engl J Med. 2007; 357(1): 39-51. PubMed Abstract | Publisher Full Text

27. Ewer SM, Ewer MS: Cardiotoxicity profile of trastuzumab. Drug Saf. 2008; 31(6): 459-67.

PubMed Abstract | Publisher Full Text

28. Ewer MS, Vooletich MT, Durand JB, et al.: Reversibility of trastuzumab-related 
cardiotoxicity: new insights based on clinical course and response to medical treatment. J Clin Oncol. 2005; 23(31): 7820-6.

PubMed Abstract | Publisher Full Text

29. Slamon D, Eiermann W, Robert N, et al.: Adjuvant trastuzumab in HER2-positive breast cancer. N Engl J Med. 2011; 365(14): 1273-83.

PubMed Abstract | Publisher Full Text | Free Full Text

30. Bowles $\mathrm{EJ}$, Wellman R, Feigelson $\mathrm{HS}$, et al: Risk of heart failure in breast cancer patients after anthracycline and trastuzumab treatment: a retrospective cohort study. J Nat/ Cancer Inst. 2012; 104(17): 1293-305.

PubMed Abstract | Publisher Full Text | Free Full Text

31. Chang HM, Moudgil R, Scarabelli T, et al: Cardiovascular Complications of Cancer Therapy: Best Practices in Diagnosis, Prevention, and Management:

Part 1. J Am Coll Cardiol. 2017; 70(20): 2536-51.

PubMed Abstract | Publisher Full Text

32. Bria E, Cuppone F, Milella M, et al.: Trastuzumab cardiotoxicity: biological hypotheses and clinical open issues. Expert Opin Biol Ther. 2008; 8(12): 1963-71. PubMed Abstract | Publisher Full Text

33. Ozcelik C, Erdmann B, Pilz B, et al.: Conditional mutation of the ErbB2 (HER2) receptor in cardiomyocytes leads to dilated cardiomyopathy. Proc Natl Acad Sci U S A. 2002; 99(13): 8880-5.

PubMed Abstract | Publisher Full Text | Free Full Text

34. Force T, Krause DS, Van Etten RA: Molecular mechanisms of cardiotoxicity of tyrosine kinase inhibition. Nat Rev Cancer. 2007; 7(5): 332-44.

PubMed Abstract | Publisher Full Text

35. Li W, Croce K, Steensma DP, et al.: Vascular and Metabolic Implications of Novel Targeted Cancer Therapies: Focus on Kinase Inhibitors. J Am Coll Cardiol. 2015; 66(10): 1160-78

PubMed Abstract | Publisher Full Text

36. Perez EA, Barrios C, Eiermann W, et al:: Trastuzumab Emtansine With or Without Pertuzumab Versus Trastuzumab Plus Taxane for Human Epidermal Growth Factor Receptor 2-Positive, Advanced Breast Cancer: Primary Results From the Phase III MARIANNE Study. J Clin Oncol. 2017; 35(2): 141-8. PubMed Abstract | Publisher Full Text | Free Full Text

37. Perez EA, Koehler M, Byrne J, et al:: Cardiac safety of lapatinib: pooled analysis of 3689 patients enrolled in clinical trials. Mayo Clin Proc. 2008; 83(6): 679-86. PubMed Abstract | Publisher Full Text

38. Swain SM, Ewer MS, Cortés J, et al: Cardiac tolerability of pertuzumab plus trastuzumab plus docetaxel in patients with HER2-positive metastatic breast cancer in CLEOPATRA: a randomized, double-blind, placebo-controlled phase III study. Oncologist. 2013; 18(3): 257-64

PubMed Abstract | Publisher Full Text | Free Full Text

39. F Naidoo J, Page DB, Li BT, et al.: Toxicities of the anti-PD-1 and anti-PD-L1 immune checkpoint antibodies. Ann Oncol. 2015; 26(12): 2375-91. PubMed Abstract | Publisher Full Text | F1000 Recommendation

40. F Champiat S, Lambotte O, Barreau E, et al:: Management of immune checkpoint blockade dysimmune toxicities: a collaborative position paper. Ann Oncol. 2016; 27(4): 559-74.

PubMed Abstract | Publisher Full Text | F1000 Recommendation

41. Weber JS, Kähler KC, Hauschild A: Management of immune-related adverse events and kinetics of response with ipilimumab. J Clin Oncol. 2012; 30(21): $2691-7$.

PubMed Abstract | Publisher Full Text

42. F Nishino M, Giobbie-Hurder A, Hatabu H, et al.: Incidence of Programmed Cell Death 1 Inhibitor-Related Pneumonitis in Patients With Advanced Cancer: A Systematic Review and Meta-analysis. JAMA Oncol. 2016; 2(12): 1607-16. PubMed Abstract | Publisher Full Text | F1000 Recommendation

43. F Johnson DB, Balko JM, Compton ML, et al:: Fulminant Myocarditis with Combination Immune Checkpoint Blockade. N Engl J Med. 2016; 375(18): 1749-55.

PubMed Abstract | Publisher Full Text | Free Full Text | F1000 Recommendation

44. F Jain V, Bahia J, Mohebtash M, et al:: Cardiovascular Complications Associated With Novel Cancer Immunotherapies. Curr Treat Options Cardiovasc Med. 2017; 19(5): 36

PubMed Abstract | Publisher Full Text | F1000 Recommendation

45. F Behling J, Kaes J, Münzel T, et al.: New-onset third-degree atrioventricular block because of autoimmune-induced myositis under treatment with antiprogrammed cell death-1 (nivolumab) for metastatic melanoma. Melanoma Res. 2017; 27(2): 155-8.

PubMed Abstract | Publisher Full Text | F1000 Recommendation

46. Cheng F, Loscalzo J: Autoimmune Cardiotoxicity of Cancer Immunotherapy Trends Immunol. 2017; 38(2): 77-8. PubMed Abstract | Publisher Full Text
47. F Chu TF, Rupnick MA, Kerkela R, et al.: Cardiotoxicity associated with tyrosine kinase inhibitor sunitinib. Lancet. 2007; 370(9604): 2011-9. PublMed Abstract | Publisher Full Text | Free Full Text | F1000 Recommendation

48. Zhu X, Stergiopoulos K, Wu S: Risk of hypertension and renal dysfunction with an angiogenesis inhibitor sunitinib: systematic review and meta-analysis. Acta Oncol. 2009; 48(1): 9-17. PubMed Abstract | Publisher Full Text

49. Wu S, Chen JJ, Kudelka A, et al.: Incidence and risk of hypertension with sorafenib in patients with cancer: a systematic review and meta-analysis. Lancet Oncol. 2008; 9(12): 117-23. PubMed Abstract | Publisher Full Text

50. Richards $\mathrm{CJ}$, Je Y, Schutz FA, et al.: Incidence and risk of congestive heart failure in patients with renal and nonrenal cell carcinoma treated with sunitinib. J Clin Oncol. 2011; 29(25): 3450-6. PubMed Abstract | Publisher Full Text

51. Ghoreschi K, Laurence A, O'Shea JJ: Selectivity and therapeutic inhibition of kinases: to be or not to be? Nat Immunol. 2009; 10(4): 356-60. PubMed Abstract | Publisher Full Text | Free Full Text

52. Kappers MH, van Esch JH, Sluiter W, et al:: Hypertension induced by the tyrosine kinase inhibitor sunitinib is associated with increased circulating endothelin-1 levels. Hypertension. 2010; 56(4): 675-81. PubMed Abstract | Publisher Full Text

53. Kappers MH, Smedts FM, Horn T, et al:: The vascular endothelial growth factor receptor inhibitor sunitinib causes a preeclampsia-like syndrome with activation of the endothelin system. Hypertension. 2011; 58(2): 295-302. PubMed Abstract | Publisher Full Text

54. Hood JD, Meininger CJ, Ziche M, et al:: VEGF upregulates ecNOS message, protein, and NO production in human endothelial cells. Am J Physiol. 1998; 274(3 Pt 2): H1054-8.

PubMed Abstract | Publisher Full Text

55. Robinson ES, Khankin EV, Choueiri TK, et al:: Suppression of the nitric oxide pathway in metastatic renal cell carcinoma patients receiving vascula endothelial growth factor-signaling inhibitors. Hypertension. 2010; 56(6): 1131-6. PubMed Abstract | Publisher Full Text | Free Full Text

56. Mayer EL, Dallabrida SM, Rupnick MA, et al:: Contrary effects of the receptor tyrosine kinase inhibitor vandetanib on constitutive and flow-stimulated nitric oxide elaboration in humans. Hypertension. 2011; 58(1): 85-92. PubMed Abstract | Publisher Full Text | Free Full Text

57. Baffert F, Le T, Sennino B, et al.: Cellular changes in normal blood capillaries undergoing regression after inhibition of VEGF signaling. Am J Physiol Heart Circ Physiol. 2006; 290(2): H547-59. PubMed Abstract | Publisher Full Text

58. Steeghs N, Gelderblom H, Roodt JO: Hypertension and rarefaction during treatment with telatinib, a small molecule angiogenesis inhibitor. Clin Cancer Res. 2008; 14(11): 3470-6.

PubMed Abstract | Publisher Full Text

59. de Jesus-Gonzalez N, Robinson E, Moslehi J, et al:: Management of antiangiogenic therapy-induced hypertension. Hypertension. 2012; 60(3): 607-15.

PubMed Abstract | Publisher Full Text | Free Full Text

60. Hasinoff BB, Patel D, O'Hara KA: Mechanisms of myocyte cytotoxicity induced by the multiple receptor tyrosine kinase inhibitor sunitinib. Mol Pharmacol. 2008; 74(6): 1722-8

PubMed Abstract | Publisher Full Text

61. Kerkela R, Woulfe KC, Durand JB, et al.: Sunitinib-induced cardiotoxicity is mediated by off-target inhibition of AMP-activated protein kinase. Clin Trans/ Sci. 2009; 2(1): 15-25.

PubMed Abstract | Publisher Full Text | Free Full Text

62. Harris IS, Zhang S, Treskov I, et al:: Raf-1 kinase is required for cardiac hypertrophy and cardiomyocyte survival in response to pressure overload. Circulation. 2004; 110(6): 718-23. PubMed Abstract | Publisher Full Text

63. Chen J, Fujii K, Zhang L, et al:: Raf-1 promotes cell survival by antagonizing apoptosis signal-regulating kinase 1 through a MEK-ERK independen mechanism. Proc Natl Acad Sci U S A. 2001; 98(14): 7783-8. PubMed Abstract | Publisher Full Text | Free Full Text

64. Cheng $\mathrm{H}$, Kari G, Dicker AP, et al:: A novel preclinical strategy for identifying cardiotoxic kinase inhibitors and mechanisms of cardiotoxicity. Circ Res. 2011; 109(12): 1401-9.

PubMed Abstract | Publisher Full Text | Free Full Text

65. Yamaguchi $\mathrm{O}$, Watanabe $\mathrm{T}$, Nishida $\mathrm{K}$, et al:: Cardiac-specific disruption of the c-raf-1 gene induces cardiac dysfunction and apoptosis. J Clin Invest. 2004; 114(7): 937-43.

PubMed Abstract | Publisher Full Text | Free Full Tex 


\section{Open Peer Review}

\section{Current Peer Review Status:}

\section{Editorial Note on the Review Process}

Faculty Reviews are review articles written by the prestigious Members of Faculty Opinions. The articles are commissioned and peer reviewed before publication to ensure that the final, published version is comprehensive and accessible. The reviewers who approved the final version are listed with their names and affiliations.

\section{The reviewers who approved this article are:}

\section{Version 1}

\section{Lee Jones}

Department of Medicine, Memorial Sloan Kettering Cancer Center, New York City, New York, USA Competing Interests: No competing interests were disclosed.

\section{Joerg Herrmann}

Division of Cardiovascular Diseases, Department of Internal Medicine, Mayo Clinic, Rochester, Minnesota, USA

Competing Interests: No competing interests were disclosed.

The benefits of publishing with F1000Research:

- Your article is published within days, with no editorial bias

- You can publish traditional articles, null/negative results, case reports, data notes and more

- The peer review process is transparent and collaborative

- Your article is indexed in PubMed after passing peer review

- Dedicated customer support at every stage

For pre-submission enquiries, contact research@f1000.com 